\title{
Typology and Factorial Conditioning of Suicidal Behavior of Adolescents
}

\section{Tipología y condicionamiento factorial de la conducta suicida de adolescentes}

\author{
Tatyana I. Bonkalo \\ Research Institute for Healthcare Organization and Medical Management of Moscow \\ Healthcare Department, Moscow, Russia \\ https://orcid.org/0000-0003-0887-4995
}

\section{Svetlana V. Shmeleva}

Moscow State University of Technology and Management K.G. Razumovsky (the First Cossack

University), Moscow, Russia

https://orcid.org/0000-0003-0390-194X

Janeta H. Sabanchieva

KBSU named after H.M. Berbekova, Nalchik, Russia

https://orcid.org/0000-0002-9103-0648

Maria.N. Tsygankova

Russian National Research Medical University named after N.I. Pirogov, Moscow, Russia Russian Academy of Education, Moscow, Russia https://orcid.org/0000-0003-1120-0684

\section{Angela V. Romanova}

Russian State Social University, Moscow, Russia https://orcid.org/0000-0002-7472-8235

Anton A. Karpinsky

Russian of Transport University, Moscow, Russia https://orcid.org/0000-0002-2144-8248

*Correspondencia

Email: bonkalotatyanaivanovna@yandex.ru 


\section{Summary}

The problem of suicidal behavior of an individual continues to remain relevant, due to the increase in the number of suicides among people of different ages, on the one hand, and insufficient information about the factors of suicidal behavior of an individual. The purpose of the study is to identify the factors that determine the formation of a certain type of personality who committed suicidal attempts in adolescence. In order to identify the types of adolescent suicides, there was conducted a survey of 20 doctors in psychiatric clinical hospitals in Moscow. The survey results were processed using cluster analysis. To identify the factorial conditioning of suicidal behavior of each personality type, a complex of psychodiagnostic techniques was used, focused on the study of the characteristics of the emotional, value-semantic and behavioral spheres of the personality. The obtained empirical data were processed with the help of factor analysis. Three clusters have been identified that combine similar personality characteristics of suicides. It was specified that among adolescents there are the following personality types: "militant" (22\%), "sacrifice" (54\%) and "self-deprecating" (24\%). Each type of adolescent suicide is due to the characteristics of the emotional, value-semantic and behavioral spheres of their personality. To develop targeted programs for the prevention of suicidal behavior among adolescents, it is necessary to take into account the results of the study, since such programs should be aimed at blocking the factors that form a certain type of suicide.

Keywords: Suicidal Behavior, Personality Type, Adolescents, Prevention Of Suicidal Behavior.

\section{Resumen}

El problema de la conducta suicida de un individuo sigue siendo relevante, debido al aumento del número de suicidios entre personas de diferentes edades, por un lado, y la información insuficiente sobre los factores de la conducta suicida de un individuo. El propósito del estudio es identificar los factores que determinan la formación de cierto tipo de personalidad que cometió intentos suicidas en la adolescencia. Para identificar los tipos de suicidios de adolescentes, se realizó una encuesta a 20 médicos en hospitales clínicos psiquiátricos en Moscú. Los resultados de la encuesta se procesaron mediante análisis de conglomerados. Para identificar el condicionamiento factorial de la conducta suicida de cada tipo de personalidad, se utilizó un complejo de técnicas de psicodiagnóstico, enfocadas al estudio de las características de las esferas emocional, valor-semántica y conductual de la personalidad. Los datos empíricos obtenidos se procesaron con la ayuda de análisis factorial. Se han identificado tres grupos que combinan características de personalidad similares a los suicidas. Se precisó que entre los adolescentes existen los siguientes tipos de personalidad: "militante" (22\%), "sacrificio" (54\%) y "autocrítico" (24\%). Cada tipo de suicidio adolescente se debe a las características de las esferas emocional, valor-semántica y conductual de su personalidad. Para desarrollar programas focalizados para la prevención de conductas suicidas entre adolescentes, es necesario tener en cuenta los resultados del estudio, ya que dichos programas deben estar dirigidos a bloquear los factores que forman un determinado tipo de suicidio.

Palabras clave: comportamiento suicida, tipo de personalidad, adolescentes, prevención del comportamiento suicida.

\section{Introducción}

The problem of suicidal behavior is recognized as one of the global problems of humanity. Over the past decades, the global suicide rate has increased by $60 \%$. According to the WHO, published on the OpenBase.online portal, in 2020 more than 50,000 suicidal cases were 
recorded in the United States, 138,000 in China, 220,000 in India, 45,178 in Russia (Ivanova et al., 2020). In Moscow in 2019, 283 suicides were recorded, which exceeds the death rate from criminal acts (Ivanova et al., 2020).

Consideration of the problems of suicidal behavior is carried out in different directions (Kholmogorova, 2016). The most common issues covered in the study of suicidal risks are the issues of their factorial causation.

In modern psychology and psychiatry, there is a fairly voluminous empirical material confirming the relationship between suicidal tendencies and depressive states of suicides. However, in order to understand the suicidal behavior of depressed patients, one cannot be limited only to indicating the depressive register; it is also necessary to take into account the personal processing of the conflict, which may be due to both pathological experiences and a real situation.

A. Beck said that suicide is based not only on depression but on a feeling of hopelessness, which can be all-consuming (Beck et al., 1999). A.G. Ambrumova believed that suicide cannot be regarded as a direct consequence of mental pathology, including the depressive register (Ambrumova, 1997).

In modern science, both mental disorders of personality (Nosov, Yurieva, 2016), severe somatic diseases (Andrianova et al., 2018; Umansky et al., 2017), and personal characteristics of suicides are considered as factors of suicidal risk: accentuations (Khritinin, Samokhin, Bunkova, 2014), value-semantic sphere of personality (Belyaeva, Molokanova, Mikitenko, 2013), nonadaptive coping strategies (Morozova, Borisenko, Evseenkova, 2019), self-rejection (Altybaeva, Ospanova, 2017), violations in decision-making (Medvedeva et al., 2016), self-doubt (Altybaeva, Ospanova, 2017), hopelessness (Beck et al., 1999), loneliness (Altybaeva, Ospanova, 2017) and other features (Rozanov et al., 2016; Uzlov, Semenova, 2017; Lakhtin et al., 2019; Golenkov et al., 2020). Researchers associate suicidal risk with dysfunctional family relationships (Bonkalo, Bonkalo, 2014; Minullina, Sarbaeva, 2015), with existing relationships in educational institutions (Altybaeva, Ospanova, 2017; Spiridonov et al., 2018), with peers and close environment (Alberdi-Paramo et al., 2020).

In Russian psychology, the concepts of suicidal behavior have been developed: the concept of A.G. Ambrumova, according to which suicidal behavior is viewed as a result of socio-psychological disadaptation of the individual in a conflict situation (Ambrumova, 1997); the theory of the historiogenesis of suicidal behavior, developed by L.N. Yuryeva, where suicidal risk is associated with the peculiarities of the era and the mentality of society (Yurieva, 2016).

Theoretical analysis showed that, firstly, the problem of identifying the factors of suicidal behavior in people of different ages is still relevant and not fully understood, and secondly, the individual originality of each suicide makes it necessary to identify personality types prone to suicidal behavior, and their factorial dependence.

The aim of the study was to identify the personality types of adolescent suicides and the factors that determine their suicidal behavior.

\section{Materials and methods}

The study was carried out at the bases of departments of Psychiatric clinical hospitals in Moscow. To identify the personality types of suicides, 20 medical workers - patients' doctors of psychiatric clinical hospitals were interviewed. Doctors were asked to characterize adolescent patients by ranking the compiled list of character traits. The results of this survey were processed with the help of cluster analysis. 
The second stage of the study was focused on identifying the factorial dependence of each type of adolescent suicide. The study involved 96 adolescents (18-23 years old) who made from one to four suicidal attempts. The study was carried out using blank questionnaires: "Test of meaningful life orientations" by J. Crumbaugh, L. Makholik as adapted by D.A. Leontyeva, A. Langle's Existence Scale, K. Orgler (adaptation by S.V. Krivtsova), Methodology "Attitude to Death" I.Yu. Kulagina, L.V. Senkevich, Methodology "Suicidal motivation" Yu.R. Vagina, "S - Test" V.L. Levy, aimed at diagnosing fears and phobias, "Scale of loneliness" D. Russell and M. Ferguson in the adaptation of N.E. Vodopyanova, Life Satisfaction Scale E. Diener, R.A. Emmons, R.J. Larsen, \& S. Griffin, Questionnaire of perceived social support by G. Sommer and T. Fyudrik (modified by A.B. Kholmogorova, G.A. Petrova), "Questionnaire of coping methods" by R. Lazarus, S. Folkman, adapted by T.L. Kryukova, Multi-factor personality questionnaire FPI (form B) as adapted by F. Korodi (Krasilnikov, 2013). Factor analysis of empirical data made it possible to identify the factor structures of each type of adolescent suicide.

\section{Results}

As a result of the cluster analysis performed with the use of Ward method, three clusters were identified that combine certain characteristics of adolescent suicides (Table 1).

Table (1): Personality types of adolescent suicides (the results of cluster analysis of a survey of doctors of mental clinical hospitals)

\begin{tabular}{|c|c|c|}
\hline Cluster names & $\begin{array}{llll}\begin{array}{l}\text { Personality characteristics of suicides } \\
\text { distribution of the trait }\end{array} & & \text { frequency } \\
\end{array}$ & $\begin{array}{l}\% \\
(\mathrm{n}=96)\end{array}$ \\
\hline "Militant" & $\begin{array}{l}\text { irritable (21), irreconcilable (18), selfish (16), cynical (14), } \\
\text { impulsive (20), conflicting (21), aggressive (20), selfish (21), } \\
\text { struggling (19), proving ( } 18) \text {, unbalanced (16), hot-tempered } \\
\text { (17), dominant (11), defiant (10), manipulative (10), self- } \\
\text { confident (10), anxious (15), hostile (17), threatening (16), } \\
\text { addicted to passions (11), unrestrained (17), embittered (19), } \\
\text { not accepting sympathy and mercy (21) }\end{array}$ & 21,88 \\
\hline "Sacrifice" & $\begin{array}{l}\text { weak (54), shy (49), unsociable (54), depressed (51), lonely } \\
\text { (52), suffering (39), unprotected (32), vulnerable (29), timid } \\
\text { (21), uncommunicative ( 54), withdrawn (54), insecure (44), } \\
\text { estranged (54), sensitive (36), sentimental (33), gentle (39), } \\
\text { schizoid (48), painful (29), amenable (31) }\end{array}$ & 54,17 \\
\hline "Self-deprecating" & $\begin{array}{l}\text { increased sense of justice (23), self-critical (23), self- } \\
\text { deprecating (23), sensitive to the opinion of others }(23) \text {, } \\
\text { dependent on the opinion of the social environment }(23) \text {, } \\
\text { emotional (23), striving for self-control (12), reserved (11), } \\
\text { correct (10), adhering to principles (10), self-destructive } \\
\text { (20), scrupulous (21), paranoid (15), not believing in } \\
\text { goodness (22), obsessed with his problems (21), too } \\
\text { concentrated (22), incapable of flexibility (20), difficult to } \\
\text { agree (19), rigid (19) }\end{array}$ & 23,95 \\
\hline
\end{tabular}

As a result of cluster and subsequent factor analysis, three types of adolescent suicides were identified, due to the content of three factors with factor loadings of more than 0,5 :

1. Emotional and personal characteristics;

2. Value-semantic factor; 
3. Factor of the characteristics of the behavioral structure of the personality, its coping strategies.

Figure 1 shows the factor structures of the first cluster, that is, the "militant" type of suicide.

Figure (1): Factor structures of the "militant" personality type of adolescent suicides

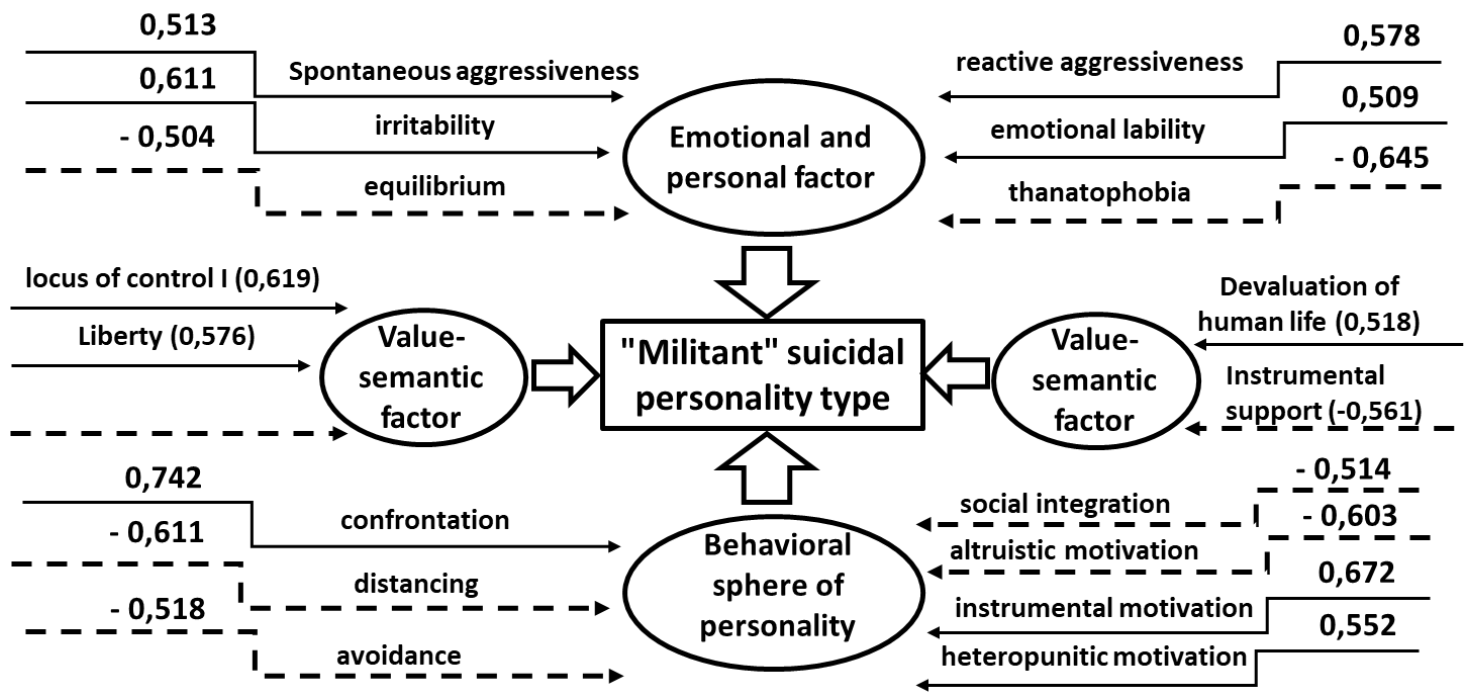

The first cluster unites the following factors and factor loadings (scales of psychodiagnostic techniques): spontaneous aggressiveness (factor loading in the first fundamental factor is 0,513 , which indicates its rather close correlation with other factor loads as part of the factor of the emotional sphere of the personality), irritability, imbalance, reactive aggressiveness, emotional lability.

The second cluster corresponds to the following factor loadings: depression, shyness, femininity, subjective feeling of loneliness, social phobia, and others.

The factor structure is shown in Figure 2.

Figure (2): Factor structures of the "sacrificing" personality type of adolescent suicides

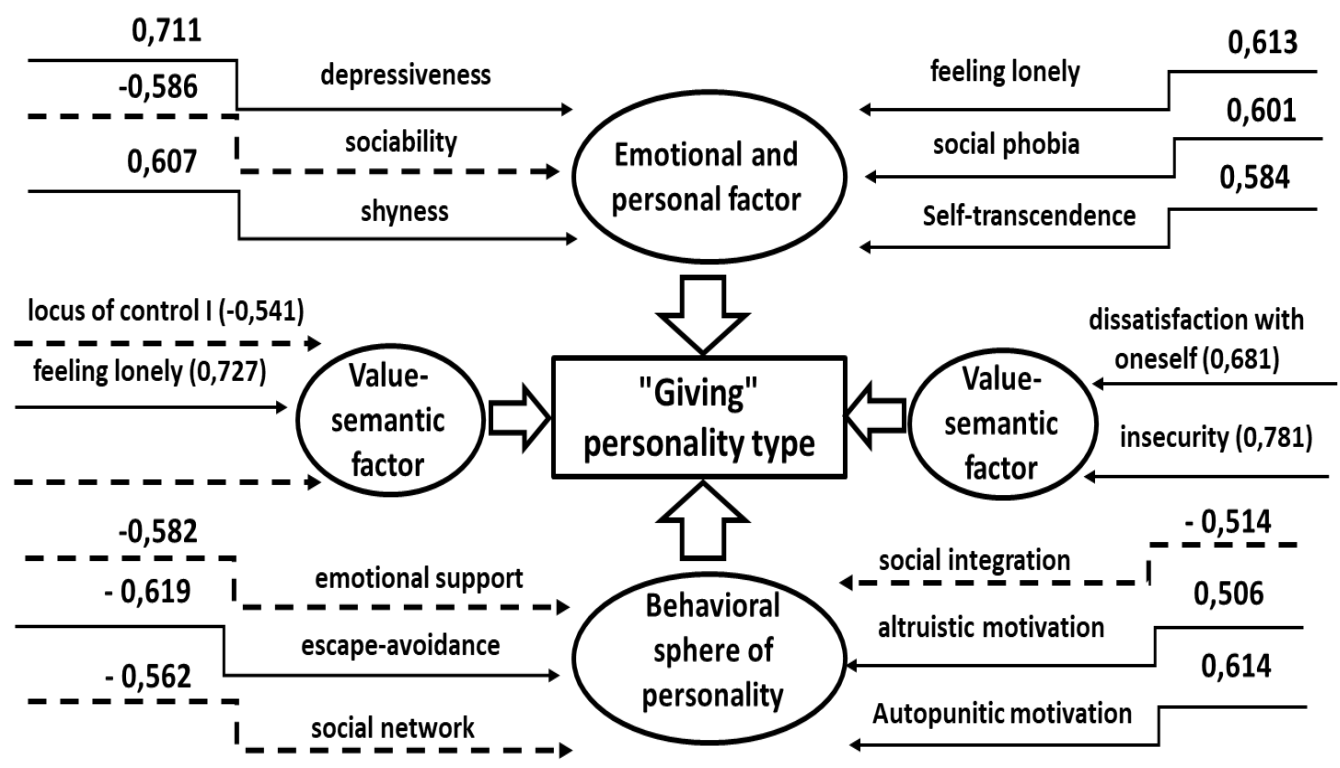


The factor structures of the third type of personality of adolescent suicides are represented by the predominance of the value-semantic factor, the explainable share of the variance of which is $24,81 \%$. Lack of goals in life, process orientation, existential problems, a positive attitude towards death - such factor loadings indicate that the semantic sphere of this type of suicidal personality is characterized by its contradictory and chaotic nature. With excessive self-criticism, a sense of responsibility, attitude towards death as a worthy end to life, there develops a feeling of guilt, which becomes a painful test for the individual. Personal characteristics, such as neuroticism, introversion, combined with the inability to establish contacts with family members and with the outside world, become a source of suicidal ideas and states.

Figure (3): Factor structures of the "self-deprecating" personality type of adolescent suicides

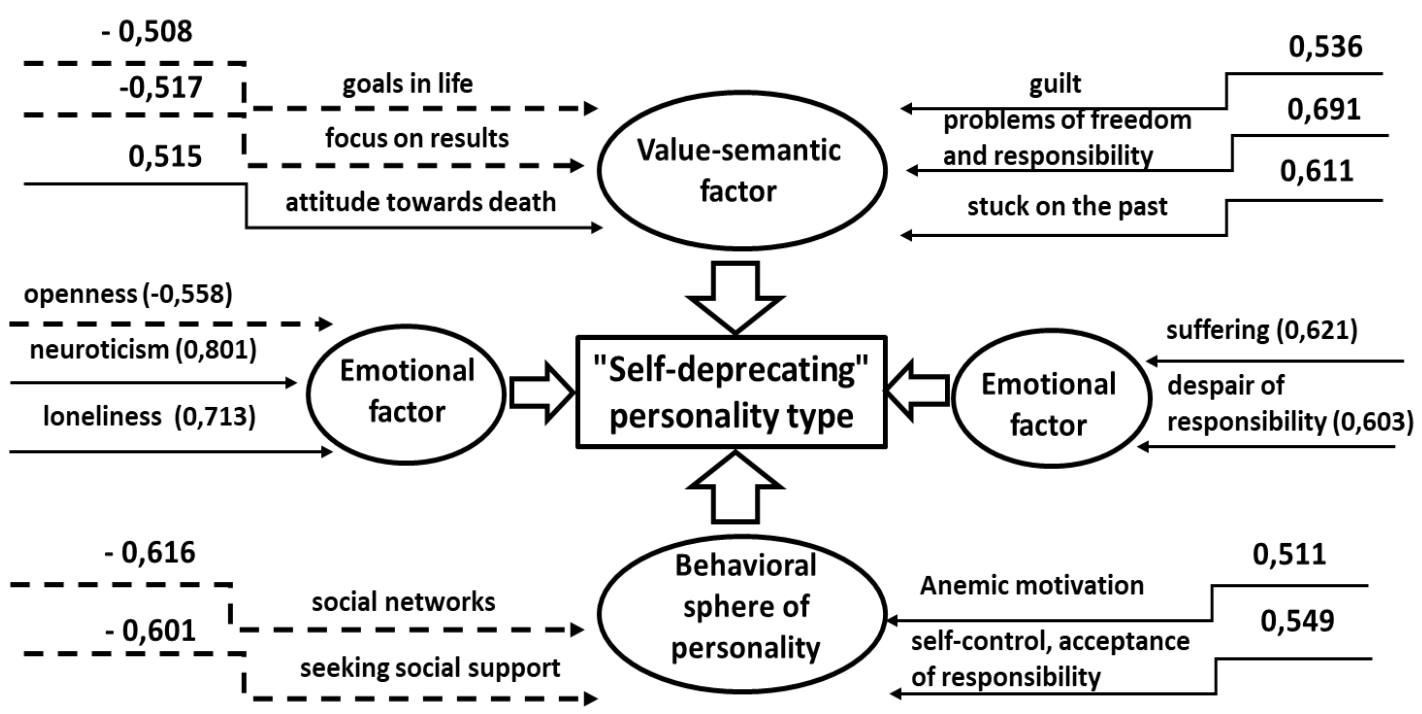

\section{Discussion}

The peculiarities of the relationship between individual indicators of the personality sphere and coping strategies of persons with suicidal behavior in adolescence make it possible to distinguish three main types of suicides.

The first type is "militant", imaginary and taking on the mission of a fighter for justice. The emergence of suicidal thoughts in this type of adolescent suicide is primarily associated with the natural feeling of the need to prove their worthiness and their point of view on the real structure of the social world.

Under normal conditions of life, their impulsiveness, spontaneous and reactive outbursts of aggressiveness, excessive emotionality, indifference to social problems in combination with egocentric tendencies of love for oneself, for one's needs and for one's own, personally significant values and at once formed ideals and priorities that correspond externally (at the first glance) with universal values and priorities, do not cause any fear, however, when faced with circumstances that prevent the satisfaction of essential needs for them, which, in fact, in proving their rightness and their point of view, in satisfying their desires, the traits of their personality and features of their personal sphere, which are expressed in the desire to prove their point by any means come into the picture.

As a rule, the typical traits of the "militant" are not shared by the close circle. The person remains alone: he is not accepted by society, he is shunned, close relationships happen extremely rarely and not for a long time. The inability to realize a high level of aspiration with minimal abilities, egocentrism, fixation on oneself, on one's problems and desires, lack of trusting relationships, rejection by society, constant struggle and confrontation in crisis 
situations lead such young men to the idea of death as a conscious departure from life, into force subjective perception of the inability to achieve their goal.

In our study, this type of personality of suicides accounted for $18 \%$ of the total number of surveyed individuals who committed suicidal attempts in adolescence.

The majority of the subjects of this age group, according to the results of the cluster analysis, represent the second type of personality, which we called "sacrifice".

According to the characteristics that made up this cluster, and taking into account the factor structures of this type, we can say that such boys and girls (in this case, the ratio of boys and girls classified as "sacrifice" is 1:5) are depressed, shy, introverted and weak.

One of the main features of their emotional sphere is their readiness for stressful responses to the most common, everyday and life circumstances. Anxiety, stiffness, an extreme degree of self-doubt, formed as a result of the peculiarities of the social situation of their development and their socialization, become a serious obstacle to the establishment of trusting relationships with other people. They are not accepted by the society, they usually become objects of ridicule in small groups. The inability to establish psychological contact with other people, an acute feeling of inferiority, combined with a high level of desire for openness in relationships, determine the formation of dependent fears - fears of being left without love, without a family, without satisfying ordinary life needs. Timidity, shyness, vulnerability determine the subjective feeling of complete loneliness, while neither hatred for others nor hatred for the circumstances of life arises due to weakness of character and lack of will. As a result of the constant resorting in difficult situations to the strategy of elimination from solving problems, immersion in one's own world of fantasy and unreality, painful thoughts accumulate and pour out in the form of the emergence of a suicidal state, characterized by dissatisfaction with oneself and the present and ideas about the impossibility of changing anything in the future. At the same time, the semantic sphere of such a person has a rather prominent meaningfulness: goals seem to exist, but life is perceived as rather complicated and not satisfying. The ability to empathize, suffer, and emotionally react to even minor circumstances and life events can become sources of self-sacrifice plans. Dissatisfaction with oneself, awareness of one's own failure, insecurity, lack of emotional support and an urgent need for it, fear of death, death, combined with the desire to prove that they are capable of an act - all this can lead to the formation of altruistic and autopunistic motivation for suicidal behavior. External causes of suicide here can be a wide variety of life events, even insignificant ones, such as nonadmission to higher educational institutions, or peers ignoring an invitation to a "party", or an imaginary conflict with parents, or subjectively perceived alienation from social actions: unjustified fear of public speaking, for example, can lead to a real stressful situation, and the need to take responsibility can lead to depression and a lack of confidence in the ability to perform normal activities for others.

The third type of adolescent suicide is called "self-deprecating". This type included $24 \%$ of persons who committed suicidal attempts in adolescence.

Based on the identified factorial structure of the personality of this type of suicide, we can say that suicidal tendencies are formed here on the basis of constant unjustified selfcriticism. In fact, this is a psychasthenic personality type that analyzes each of its actions and controls it in terms of predicting the reaction to these actions of other people. As a rule, selfflagellation, self-torture, attempts to take full responsibility for a difficult life situation and the insolubility of problems lead to a state of excessive psychoemotional stress, to psychological discomfort of the individual. The restoration of emotional balance is impossible, due to the unexplored skills of solving problem situations. 
The emotional sphere of this type of personality of suicides is characterized by a low level of development of the ability to move away from their experiences and rationally think in situations that require a decision. Neuroticity as a characteristic of a sufficiently high level of neurotization of this type of personality is due to the same self-criticism of their actions and deeds. The subjective feeling of loneliness, due to a negative assessment of one's personality traits, leads to the emergence and development of an existential personality crisis even in moments of age-related developmental crises. Dissatisfaction with oneself, one's present, agonizing problems of freedom and responsibility, deep feelings of guilt, suffering, despair, unsuccessful attempts to control oneself in difficult life situations, take responsibility for them, evaluate one's role and one's actions as the main source of problems can lead to the emergence of a suicidal state and the thought that only withdrawal from life is the only sure way to end the unbearable torments of "self-criticism" and self-torture.

The semantic sphere of this type of personality is characterized by its lack of meaning, the absence of clearly set goals in the future, the attitude towards life as a meaningless existence, leading to unbearable torment and the inability to be their true self.

Thus, all three personality types of adolescent suicides were represented in our study.

\section{Conclusion}

In adolescence, the emergence and development of suicidal behavior may be due to the complex of individual psychological characteristics of a person who has fallen into a difficult life situation and intensified by age-related development crises, which has a variable content that reflects the specifics of the personal sphere and coping behavior of individuals, which determine the three main personality types adolescent suicide: "militant" (aggressive, irritable, impulsive, stuck on his unmet need to be recognized) "sacrifice" (deprived of both social support and real social contacts) and "self-deprecating" (excessive self-criticism of all the measures taken by).

To develop targeted programs for the prevention of suicidal behavior in adolescents, it is necessary to take into account the results of the study, since such programs should be aimed at blocking the factors that form a certain type of suicide.

\section{Referencias}

Alberdi-Paramo, I., Saiz-Gonzalez, M.D., Diaz-Marsa, M., Carrasco-Perera, J.L. (2020). Bullying and childhood disorder: Preliminary findings. Psychiatry Research, 285. https://doi.org/10.1016/j.psychres.2019.112730

Altybaeva, G.K., Ospanova, N.N. (2017). Assessment of suicidal risk in first-year students of a medical university (panel research). Science and health care, 2: 48-58.

Ambrumova, A.G. (1997). Psychology of Suicide. Social and Clinical Psychiatry, 4: 14-20.

Andrianova, M.A., Buddy, V.A., Sereda, A.P., Tarasova, T.B., Fedotov, D.D. (2018). Algorithm for detecting suicidal risk in patients by medical personnel. Medicine of extreme situations, 20(4): 541-545.

Beck, A.T., Brown, G.K., Steer, R.S., Dahlsgaard, K.K., Grisham, J.R. (1999). Suicide ideation at its worst point: A predictor of eventual suicide in psychiatric outpatients. Suicide and Life-Threatening Behaviors, 29: 1-9.

Belyaeva, A.V., Molokanova, Yu.P., Mikitenko, A.A. (2013). The relationship between lifemeaning orientations and suicidal risk in senior students. Apriori. Ser.: Natural and technical sciences, $1: 7$.

Bonkalo, S.V., Bonkalo, T.I. (2014). The relationship of suicidal intentions of adolescents with socio-psychological characteristics of their personality, in: Materials of the III All-Russian Scientific and Practical Conference "Socio-psychological prevention and psychotherapy of the suicidal state of the individual". Moscow: RGSU. 
Golenkov, A.V., Madyanov, I.V., Shmeleva, S.V., Petrova, G.D., Kamynina, N.N., Logachev, N.V. (2020). The relationship between body mass index and mental disorders in the adult population. Healthcare of the Russian Federation, 64(6): 336342.

Ivanova, A.E., Aksenova, E.I., Sabgaida, T.P., Semenova, V.G., Evdokushkina, G.N., Rudnev, S.G., Tarasov, N.A. (2020). Analysis of multiple causes of death on the eve of ICD-11: a collective monograph. Moscow: NIIOZMM DZM.

Kholmogorova, A.B. (2016). Suicidal behavior: a theoretical model and practice of assistance in cognitive-behavioral therapy. Counseling psychology and psychotherapy, 24(3): 144-163. https://doi.org/10.17759/cpp.2016240309

Khritinin, D.F., Samokhin, D.V., Bunkova, K.M. (2014). The influence of personal accentuations on the risk of suicidal manifestations in students, in: Modern ways of development of psychiatry: a collection of materials of an interregional scientificpractical conference with international participation. Tula.

Krasilnikov, I.A. (2013). Workshop: research of the existential-being sphere of personality. Saratov: GSU.

Lakhtin, A.Y., Shmeleva, S.V., Gulyaev, A.A., Vakulenko, A.N., Logachev, N.V. (2019). Possibilities of logorhythmics in the development of preschoolers with mental retardation. Biomedical and pharmacology Journal, 12(2).

Medvedeva, T.I., Vorontsova, O.Yu., Enikolopov, S.N., Kazmina, O.Yu. (2016). Violation of decision making and suicidal tendencies. Psychological research, 9(46): 3.

Minullina, A.F., Sarbaeva, O.Yu. (2015). The relationship between the factors of family education and suicidal activity of adolescents. Practical medicine, 5(90): 27-30.

Morozova, I.S., Borisenko, Yu.V., Evseenkova, E.V. (2019). The current state of research into the risk of suicidal personality behavior. Society: sociology, psychology, pedagogy, 11: 1-9.

Nosov, S.G., Yurieva, L.N. (2016). Suicidal activity of patients with epilepsy during treatment with antiepileptic drugs. Suicidology, 7(1(22)): 55-63.

Rozanov, V.A., Ukhanova, A.I., Volkanova, A.S., Rakhimkulova, A.S., Pizarro, A., Biron, B.V. (2016). Stress and suicidal thoughts in adolescents. Suicidology, 7(3(24)): 2032.

Spiridonov, E.A., Shmeleva, S.V., Mikhailova, I.V., Karpov, V., Eremin, M.V., Maskaeva, T. (2018). Adaptive resource of disabled persons with late affection of the musculoskeletal system. Prensa Medica Argentina, 104(2).

Umansky, M.S., Zotov, P.B., Abaturova, O.V., Zhmurov, B.A., Rodyashin, E.V., Prilensky, A.B. (2017). Suicide and cardiovascular disease: is there a relationship? Suicidology, 8(3(28)): 94-99.

Uzlov, N.D., Semenova, M.N. (2017). Game, transgression and network suicide. Suicidology, 3(28): 40-53.

Yurieva, L.N. (2016). Clinical suicidology. Dnepropetrovsk. 